\title{
An improvement of tribological properties of boron alloyed layers
}

Ivan Kováč ${ }^{1}$ - Jozef Žarnovský ${ }^{1}-$ Róbert DRLIČKA $^{1}$ - Juraj Ružbarský ${ }^{2}$

${ }^{1}$ Technical faculty, Slovak University of Agriculture of Nitra, Tr. A. Hlinku 2, 94976 Nitra

${ }^{2}$ Faculty of Manufacturing Technologies of the Technical University of Košice with a seat in Presov, Štúrova 31,08001

Prešov, Slovak Republik

In presented paper we described studies of resistance of selected material in abrasive wear tests. A surface of tested materials was remelted with TIG method in a compound of gases of argon and $\mathrm{B}_{4} \mathrm{C}$. Analysing tests results we found out, that the most abrasive wear resistant material was sample of steel 11373 and 12050 . The process of remelting by using electrical arc in gas atmosphere generates the conditions that allow creation of steady structures of mechanical properties and higher wear resistance. Materials 11373 and 12050 were used for verifying those facts with comparison to etalon 12014.

Key words: abrasion, shield, friction.

\section{References}

[1] BLAŠKOVIČ, P. - BALLA, J. - DZIMKO, M. 1990. Tribológia, Bratislava, Alfa 1990, ISBN 80-05-00633-0, $360 \mathrm{~s}$,

[2] MÜLlER, M., VALÁŠEK, P., 2010. Polymerní kompozity na bázi zpevňujících částic odpadů z procesu mechanické povrchové úpravy. In Strojírenská technologie, 2010, roč. 14, č. zvláštní číslo, s. 183 - 186. ISSN 1211-4162.

[3] RY Š, P. et al., 1975. Nauka o materiálu 1, Praha, Academia, 1975.

[4] STN 015084 : Stanovenie odolnosti kovových materiálov proti abrazívnemu opotrebeniu.

Reviewers:

Prof. Bruno Sopko, Ph.D., Sc.D. Prof. Jiři Petruželka, MSc., Ph.D. 